\title{
Buyouts are Here to Stay
}

\section{Ranko Jelic*}

Department of Finance, University of Birmingham, UK

\section{Introduction}

Consistent with Jensen's [1] predictions, the buyout market has grown tremendously since the 1980s. Buyout transactions, for example, account for more than one half of all private equity (PE) investments, estimated to be worth about $\$ 2.5$ trillion worldwide [2]. The US, Asian and European buyouts exhibit many similar features. This is explained by dominance of internationally transmitted financial technology over institutional and business cultural factors [3]. Globally, the US market still receives the highest amount of PE investments followed by the UK market. The unprecedented growth of UK PE backed buyouts generated public interest and, at the same time, created some controversy regarding buyouts and the role of PE investors. For example, media and some politicians often accuse PE firms of shorttermism (i.e. exiting too early) and lacking to improve the buyouts' performance. The PE industry (e.g. British Private Equity and Venture Capital Association BVCA), on the other hand, argues that PE firms work longer with their targets and that companies backed by PE have performed better than other companies. In this editorial article, we summarise recent literature that examines longevity of UK buyouts thus shedding more light on the above controversy. We also discuss limitations of the previous research and suggest some interesting areas for future research.

\section{UK Buyout Exits and Longevity - Survey of the Recent Literature}

We survey research that is based on buyout level rather than at PE fund level data. Aggregation of data at the PE fund level inevitable leads to loss of information regarding timing of original investments and exits from buyout structure. Company level data, on the other hand, allow researchers to monitor the exit status and, therefore, longevity of buyouts. The buyout level data also allows researchers to control for the fact that PE investors tend to prefer investments in companies with certain characteristics.

Overall, IPOs and sales are the preferred exit route for UK buyouts [4]. The UK has the most liquid PE and stock markets in Europe which helps explaining the popularity of IPO exits in UK compared to other European countries. The reported evidence on the importance of IPOs as exit route for UK buyouts, however, varies significantly. For example, the reported percentages for IPO exits from UK buyouts were $16 \%$ in Nikoskelainen and Wright [5], 10\% by Wright et al. [6], $11 \%$ by Stromberg [7] and $47 \%$ by Jelic [4]. Most recently, SMBO exits exhibited steady growth, reaching $29 \%$ of all exits in the 2000s [4].

Stromberg [7] reports that only $2.9 \%$ of PE backed deals worldwide exited within 12 months of the original transaction. Jelic [4] reports higher percentage of the early exits for UK buyouts, of 5.1\%. The UK early exits tend to be associated with IPOs of relatively smaller buyouts at the AIM [4]. Both studies report that number of early exits exhibited a decreasing trend over the last three decades. The reported failure rates for UK buyouts are similar to failure rates of $3 \%$ reported for other UK private firms.

Jelic [4] reports median time to exit of 36 months for UK buyouts. Around $35 \%$ of UK buyouts remained in a buy-out organisational form, whilst $47 \%$ remained in private ownership for at least 7 years after the original buyout transactions. The results are in line with the results reported in Stromberg [7] who reports that while $67 \%$ of his UK sub-sample exited the original LBO structure during the sample period, 59\% exited LBO organisational form within 5 years after the original LBO. Buyout characteristics (e.g. size), characteristics of PE backing (e.g. syndicates and highly leveraged deals), together with stock market and PE market conditions significantly influence the longevity of buyouts [4].

The average time to exit in UK PE backed subsamples ranges from 3.3 years [4] to 3.5 years [5]. This compares to 3.7 years reported for European PE backed deals [8]. Across exit routes, the longevity of UK PE backed IPOs (3.2 years as reported in Jelic [4]) is similar to the average longevity reported for European deals (3.3 years as reported in Cumming [9]). The combined average longevity of private exits (sale and SMBO) of 3.6 years [4] is slightly longer than 3.4 years reported for European deals in Cumming [9]. The longevity, however, is longer than for the US (3.0 years) and Canadian (2.5 years) VC backed IPOs [10] The only notable difference is the longevity of PE backed liquidations (4.4 years as reported in Jelic [4]) compared to the longevity of writeoffs reported for European deals (3.6 years as reported in Cumming [9]). Finally, the longevity of SMBO exits was 4.3 years [4].

Overall, the above evidence suggests that majority of UK buyouts survive longer than 3 years while more than one third survives longer than 10 years in a buyout form. Although PE backed deals exhibited shorter average longevity than their non-PE backed counterparts, we found no evidence of alleged systematic short-termism of PE firms. The above results are also in line with a lack of evidence that the PE industry contributed to the recent financial crisis and evidence suggesting statistically significant increases in the operating performance of UK buyouts [11]. Furthermore, regulators have recognized that private equity offers a compelling business model with significant potential to enhance the efficiency of companies both in terms of their operations and their financial structure [12]. At European level, 2011 EU Directive on Alternative Investments (including PE) has been significantly 'soften' which is consistent with the view that initial post-crisis rhetoric against PE sector was (at least partly) politically motivated. The association of buyout and public ownership has increasingly being seen as one of symbiotic rather than of competitive nature.

\section{Concluding Remarks}

\section{Data matters}

Limitations of the various databases on PE backed buyouts have

${ }^{*}$ Corresponding author: Ranko Jelic, Professor, Department of Finance, University of Birmingham, UK, Tel: 44-0-121-414-5990; Fax: 44-0-121-414-6238; E-mail: R.Jelic@bham.ac.uk

Received July 24, 2012; Accepted July 25, 2012; Published July 27, 2012

Citation: Jelic R (2012) Buyouts are Here to Stay. J Bus \& Fin Aff 1:e111. doi:10.4172/2167-0234.1000e111

Copyright: (c) 2012 Jelic R. This is an open-access article distributed under the terms of the Creative Commons Attribution License, which permits unrestricted use, distribution, and reproduction in any medium, provided the original author and source are credited. 
been discussed in the buyout literature [7,13-15]. For example, Capital IQ database lacks data on enterprise values and pricing for more than $58 \%$ of the transactions [7]. Furthermore, several databases have a specific threshold for size of transaction (e.g. Thomson One Banker). Since buyouts may have been relatively small at the time of the buyout but have subsequently grown to a size where an exit (e.g. IPO) is feasible, the data sources that adopt a large minimum size cut-off may have introduced a biased perspective [14]. Furthermore, the majority of databases (e.g. Thomson One Banker, Capital IQ and SDC M\&A) have more observations in recent years, which inevitable creates a sample selection bias. Other potential problems with sample selection (and endogeneity) were also discussed in some of the previous studies $[4,14,16,17]$. Cochrane [17], for example, highlights the importance of addressing potential selection problems in the sample consisting of exited investments only. Cumming and MacIntosh [16] and Jelic et al. [14] address the potential endogeneity problem due to the possibility that PE firms do not randomly select buy-outs they are backing. The above issues continue to create challenges and need to be addressed by researchers in this area.

\section{Suggestions for future research}

The alignment of incentives leading to improved performance lies at the heart for management buyout organizational form [18]. At the same time, finance literature recognizes that activities of PE investors (e.g. monitoring, advising, etc.) could increase firms' market value [19]. There is however paucity of literature that examines whether and if yes how these PE activities contribute over and above the benefits of buyout ownership associated with the alignment of incentives in closely held companies. Comparison of performance and longevity of PE backed and non-PE backed (i.e. pure) buyouts thus presents a promising avenue for future research.

While public-to-private buyout transactions tend to receive most of the media and attention by regulators, they represent less than $7 \%$ of all buyout transactions, worldwide [7]. The vast majority of buyout targets, therefore, are private companies and these transactions often use little or no leverage. Future research, therefore, should focus more on private-to-private and private-to-public as opposed to highly leveraged public-to-private buyout transactions.

Finally, a more detailed investigation of SMBOs as one of the important exit routes in the post-Lehman period would also be an important contribution to the literature. For example, it is still not clear whether SMBOs just buy more time for PE firms unable to exit their investments via IPOs or they tend to create value for investors.

\section{References}

1. Jensen MC (1989) Eclipse of the Public Corporation. Harvard Business Review.

2. http://www.thecityuk.com/assets/Uploads/Private-equity-2010.pdf

3. Cumming DJ, Fleming G (2012) Barbarians, Demons and Hagetaka: A Financial History of Leveraged Buyouts in Asia 1980-2010.

4. Jelic R (2011) Staying Power of UK Buy-Outs. J Bus J Financ Account 38: 945-986.

5. Nikoskelainen E, Wright M (2007) The Impact of Corporate Governance Mechanisms on Value Increase in Leveraged Buy-outs. J Corp Financ 13: 511537.

6. Wright M, Thompson S, Robbie K, Wong P (1995) Management Buy-outs in the Short and Long Term. J Bus Financ Account 22: 461-482.

7. Stromberg P (2008) The New Demography of Private Equity. The Global Impact of Private Equity Report 2008.

8. Schwienbacher A (2002) An Empirical Analysis of Venture Capital Exits in Europe and the United States.

9. Cumming D (2008) Contracts and Exits in Venture Capital Finance. Rev Financ Stud 21: 1947-1982.

10. Cumming DJ, Johan S (2010) Venture Capital Investment Duration. J Small Bus Manage 48: 228-257.

11. Jelic R, Wright M (2011) Exit, Performance, and Late Stage Capital: the Case of UK Management Buyouts. Eur Financ Manage 17: 560-593.

12. http://www.fsa.gov.uk/pubs/discussion/dp06_06.pdf

13. Kaplan S, Sensoy B, Stromberg P (2002) How Well Do Venture Capital Databases Reflect Actual Investments?

14. Jelic R, Saadouni B, Wright M (2005) Performance of Private to Public MBOs: The Role of Venture Capital. J Bus Financ Account 32: 643-682.

15. Ball ER, Chiu HH, Smith RL (2008) Exit Choices of Venture-Backed Firms: IPO v. Acquisition.

16. Cumming DJ, MacIntosh JG (2001) Venture Capital Investment Duration in Canada and the United States. Journal of Multinational Financial Management 11: $445-463$.

17. Cochrane J (2005) The Risk and Return to Venture Capital. J Financ Econ 75 3-52.

18. Jensen MC, Meckling WH (1976) Theory of the firm: Managerial behavior, agency costs and ownership structure. J Financ Econ 3: 305-360.

19. Kaplan S, Stromberg P (2009) Leveraged Buyouts and Private Equity. Journa of Economic Perspectives 23: 121-146. 